\title{
Numerical Modeling, Simulation and Validation of Hybrid Solar Photovoltaic, Wind Turbine and Fuel Cell Power System
}

\author{
S. Sami* and D. Icaza
}

\author{
Center for Renewable Energy, Catholic University of Cuenca, Cuenca, Ecuador
}

\begin{abstract}
The energy conversion equations describing the total power generated by a hybrid system of solar photovoltaic, wind turbine, fuel cell as well as hydrogen storage were presented, and integrated simultaneously. For the purpose of validating, this simulation model, the aforementioned equations were coded with MATLAB V13.2 and used for optimization and design purposes. A block diagram approach was used during the simulation with MATLAB. In order to validate and tune up the predicted output results, on-site data was used to validate the simulation program under various conditions. Comparison between the data and predicted results showed a fair agreement.
\end{abstract}

Keywords: Modeling, Simulation, Hybrid System, Photovoltaic, Wind turbine, Fuel Cell, Hydrogen Storage, Experimental Validation.

\section{INTRODUCTION}

There are many reasons for using distributed generation such as for standby or emergency generation as well as backup. Also it has great potential as green power source for renewable technology and particularly for electrification of remote locations disconnected from the grid [1]. Renewable and nonconventional methods of power generation such as wind, solar, hydraulic, biomass, geothermal, thermal storage and waste heat recovery power generations as well as fuel cells offer supply solutions for remote areas, not accessible by grid power supply and in use of distributed generation. Integrated system of two or more renewable energy systems, also known as hybrid renewable energy system, is becoming popular because these sources can complement each other, provide higher quality and more reliable power supply independent of the grid and electrify rural areas [2-4].

Of a particular interest is the electrification of rural area and power standalone systems; solar and hybrid; solar-wind, solar-wind-fuel cell, solar-hydro, solar-winddiesel, and solar-wind-diesel-hydro/biogas hybrid have been presented and discussed by reference [5]. The viability and importance of solar energy use in global electrification and hybrid power systems also have been presented in that reference and analyzed. Another study was also proposed by Bhandari [6] for implementation in rural area disconnected from the grid. The study discussed two tri-hybridization processes. The tri-hybrid system included hydro-wind

*Address correspondence to this author at the Center for Renewable Energy, Catholic University of Cuenca, Cuenca, Ecuador; Tel: 760476 9256; Fax: 760 476 9257; E-mail: dr.ssami@transpacenergy.com and Photovoltaic. On the other hand, Mahallakshmi, and Latha [7] focused on the modeling and simulation of solar-photovoltaic, wind and fuel cell hybrid energy systems using MATLAB/Simulink software. The simulation results of the $\mathrm{PV} /$ wind/Fuel cell hybrid systems were presented in graph showing the effectiveness of the proposed system model. Also, another hybrid photovoltaic-fuel cell generating system employing an electrolyzer for hydrogen generation was designed and simulated by Maharia and Dalal [8]. This system is applicable to remote areas or isolated loads. The system included a controller designed to achieve permanent power supply to a load via PV array or a fuel cell or both. Kumar and Garg [9] study dealt with a detailed hybrid model of a solar/ wind and fuel cell in Simulink. They developed a high efficient model and compared with a hybrid model using battery as a storage system instead of fuel cell. This study described solar-wind hybrid system for supplying electricity to power grid. Furthermore, another potential solution for stand-alone power generation was presented by Touati et al. [10] for a hybrid energy system in parallel with some hydrogen energy storage. In this study the hybrid PV, fuel cell generation employed an electrolyzer using reverse osmosis for hydrogen generation that is applicable to desalination plant loads. The reverse osmosis was electrically driven by the PV.

The sequence of operation of power sources such as hydro, wind, $\mathrm{PV}$, biogas and diesel engine have simulated and analyzed hour by hour in MATLAB by Saha et al. [11]. In the simulation, it was proposed a hypothetical hybrid system that employed the aforementioned hybrid systems. However, their analysis did not consider synchronization of the different power systems discussed. Furthermore, 
Mutafa [12] presented an algorithm for sizing and simulation of PV-Wind hybrid power system that can simulate the annual performance of different kinds of these systems structures. For validating the proposed the model, his proposed algorithm was coded and simulated with MATLAB V7.7 that also was employed as a software tool during the simulation. The daily source data were calculated using monthly mean solar radiation and wind speed. Saib and Gherbi [13] presented and discussed a design of a hybrid power system for PV, wind turbine and battery connected to the grid. Their modeling and simulation used MATLAB/Simulink and SimPower system environment. They concluded that future work should be oriented and realized towards the optimization of the aforementioned hybrid systems in order to reduce the generation cost and maximize the output power.

This paper presents a numerical approach that can determine the optimal design of a hybrid solar photovoltaic, wind turbine and fuel cell power system for either on or off the grid applications. This particular hybrid power generation system is of a particular interest since the fuel cell is driven by part of electricity generated by the solar photovoltaic, and wind turbine. The end result is a more efficient energy conversion as well as power generation for either off the grid or on the grid. The technique presented hereby uses the conversion energy equations and linear programming principles. Numerical simulation of the hybrid system under investigation was carried out by using MATLAB. Furthermore, this paper is concerned with the prediction of energy conversion of renewable energy sources such as solar radiation, wind velocity, hydrogen storage into electrical energy and the conversion efficiency.

This paper also describes the simulation, of a combined wind, solar and fuel cell/hydrogen storage system for electric power generation with electrical energy storage facilities that can be used during low solar radiation and/or wind speeds. Multivariable weather data including the wind speed and direction, the solar radiation, the rain fall and humidity as well as temperature were obtained using a weather station installed at University. Moreover, the simulation model includes modern load controller and inverter. The following describes the simulation model, energy conversion equations, as well as energy conversion efficiencies and linear programming principles as well as description of MATLAB block diagrams;

\section{MATHEMATICAL MODELING}

In the following sections, the energy conversion equations for each source of renewable energy to an electrical energy are presented;

\section{Wind Power System} [3];

The power of a particular wind turbine is given by

$P_{W T}=0.5 * C_{p} * \rho_{a i r} * v^{3} * \eta_{\text {aer }}$

Where; $P_{W T}$ Wind power sweep produced by the blades per unit area. $C_{p}=$ Betz power coefficient. $\rho_{\text {air }}=$ Air density and $v$ is the wind velocity.

Taking into account the internal performance of the wind turbine, the following can be written;

$\eta_{\text {aer }}=\eta_{\text {fmec }} \cdot \eta_{g} \cdot \eta_{m p}$

Where; $\eta_{\text {fmec }}, \eta_{g}$ are mechanical friction and generator efficiencies respectively and the efficiency speed multiplication box is $\eta_{m p}$.

The power output of the wind turbine in equation (1) can be expressed in three-phase power AC as;

$P_{3 f}=3 . \eta_{\text {c1 }} \cdot U_{\text {line }} \cdot I_{\text {line }} \cdot \operatorname{Cos} \varphi$

With three phase AC power is $P_{3 f}$ line current $I_{\text {line }}$ represents power factor $\operatorname{Cos} \varphi$, and the electric conversion efficiency is referred to as $\eta_{c 1}$.

\section{Photovoltaic PV System}

The thermal energy absorbed by the PV solar collector is [1, 3];

$P_{P V}=\eta_{p v g} A_{p v g} G_{t}$

Where $\eta_{p v g}$ is PV solar collector efficiency, $A_{p v g}$ is PV solar collector area $\left(\mathrm{m}^{2}\right)$, and $G_{t}$ is solar irradiation $\left(\mathrm{W} / \mathrm{m}^{2}\right)$ and $\eta_{p v g}$ can be defined as [1];

$\eta_{p v g}=\eta_{r} \eta_{p c}\left[1-\beta\left(T_{c}-T_{c r e f}\right)\right]$

Where $\eta_{p c}$ is power conditioning efficiency which is equal to one when maximum power point tracking (MPPT) is used, and $\beta$ is temperature coefficient $\left((0.004-0.006)\right.$ per $\left.{ }^{\circ} \mathrm{C}\right)$, and $\eta_{r}$ is the reference module efficiency, and $T_{\text {cref }}$ is the collector reference temperature. 
The electric PV power output in DC taking into account the efficiency of conversion to electric energy is;

$P_{P V}(t)=\eta_{c 2} I_{P V}(t) . V_{P V}(t)$

Where $\eta_{c 2}$ is the efficiency of conversion to DC and referred to $V_{P V}(t)$ and $I_{P V}(t)$.

\section{Fuel Cell/ Hydrogen Storage Power System}

\section{Electrolyzer}

In general, the power to electrolyzer is driven by part of the solar panels to produce hydrogen. Each electrode has a single polarity producing either $\mathrm{H}_{2}$ or $\mathrm{O}_{2}$. The operating temperature of the electrolyzer does not exceed $70{ }^{\circ} \mathrm{C}$. This model considers the Proton Exchange Membrane Fuel Cell (PEMFC). The electrolyzer is composed of a number of isolated cells [10]. The hydrogen production rate is given by [10, 14];

$X_{H}=5.18 \times e^{-6} I_{e}(\mathrm{~mole} / \mathrm{s})$

Where $\mathrm{I}_{e}$ is the current between electrodes, $\mathrm{H}_{2}$ is stored in a tank normally under 3 bars and feeds then fuel cell. [10];

The energy in the form of hydrogen is calculated by

$\mathrm{E}_{\mathrm{H} 2}=\mathrm{Load} / \mathrm{\eta}_{\mathrm{FC}}$

Where the load is represented by the maximum and minim quantity of energy storage in $\mathrm{KWhr}$ and $\eta_{\mathrm{FC}}$ is the efficiency of fuel cell.

Therefore, the mass of hydrogen is calculated as;

$m_{\mathrm{H} 2}=\mathrm{E}_{\mathrm{H} 2 /} \mathrm{HCV}_{\mathrm{H} 2}$

Where $\mathrm{HCV}_{\mathrm{H} 2}$ is the higher calorific value of hydrogen $(\mathrm{kWhr} / \mathrm{kg})$ and the volume $\mathrm{V}_{\mathrm{H} 2}$ can be calculated from the perfect gas equation [14];

\section{Hydrogen Tank}

$\mathrm{Pv}=\mathrm{nRT}$

Where $R$ is the constant for perfect gas and is NA.KB with NA is the number of Avogadro and KB is the Boltzmann constant, $v$ is the gas specific volume and $\mathrm{n}$ represents the number of moles.

Hence, the energy required for compressing the $\mathrm{H}_{2}$ is [15];
$E_{\text {compressor }}=m_{H 2} \times(\gamma-1) / \gamma\left(P_{e} V_{0} / \eta\right)\left\{\left(P_{s} P_{e}\right)^{\gamma-1 / \gamma}-1\right\}$

Where, $\mathrm{m}_{\mathrm{H} 2}$ is the Hydrogen mass, and $\mathrm{V}_{0}$ represents initial specific volume of hydrogen. $P_{e}$ and $P_{s}$ are entry and exit pressures of the compressor.

The electric fuel cell power output in DC can be expressed as following;

$P_{F C}(t)=\eta_{c 3} I_{F C}(t) \cdot V_{F C}(t)$

Where the overall output of the fuel cell stack can be obtained as [7];

$\mathrm{V}_{\text {stack }}=\mathrm{E}_{\text {nernst }}-\mathrm{V}_{\text {act }}-\mathrm{V}_{\text {ohm }}-\mathrm{V}_{\text {con }}$

With $\mathrm{E}_{\text {nernst }}, \mathrm{V}_{\mathrm{act}}, \mathrm{V}_{\mathrm{ohm}}$, and $\mathrm{V}_{\text {con }}$ are Nernst, activation, Ohmic and concentration voltages, respectively.

The $E_{\text {nernst }}$ represents the thermodynamic potential drop in the cell and is calculated as a function of the change in the free Gibbs energy reaction and can be calculated as per expression reported by [7]. The activation over potential, Ohmic voltage drop and concentration voltage drop are calculated using expressions provided by Najafizadegan and Zarabadipour [14].

\section{Controller}

Generally, the controller power output is given by;

$P_{\text {Cont-dc }}=V_{\text {bat }}\left(I_{\text {rect }}+I_{P V}+I_{F C}\right)$

Where; $V_{\text {bat }}$ is multiplication of the nominal voltage $D C$ in the battery for any particular system and $I_{r e c t}, I_{P V}$ and $I_{F C}$ represent the output current of the rectifier in $\mathrm{DC}$ and currents of $\mathrm{PV}$ and fuel cell.

\section{Battery Performance Model}

Normally, batteries in a hybrid system are connected in series to obtain the appropriate nominal bus voltage. Therefore, the number of batteries connected in series in a battery banks is calculated as follows;

$N_{S B a t}=\frac{V_{P V}}{V_{B a t}}$

\section{Inverter, Charger, and Loads Performance Model}

The characteristics of the inverter are given by the ratio of the input power to the inverter $P_{i n v-i p}$ and inverter output power $P_{i n v-o p}$. The inverter will incur 
conversion losses and to account for the inverter efficiency losses, $\eta_{i n v}$ is used;

$P_{i n v-i p}, \eta_{i n v}=P_{i n v-o p}$

In many applications, load may not be served with the desired amount of energy. This situation is described as loss of load probability (LLP) and can be calculated using the following equation and also, LLP can represent the system reliability [13];

$$
L L P=\frac{\text { Energy__Demand }}{\text { Energy_Served }}
$$

The AC power of the inverter output $P(t)$ is calculated using the inverter efficiency $\eta_{i n v}$, output voltage between phases, neutral $V_{f n}$, for single-phase current $I_{o}$ and $\cos \varphi$ as follows;

$$
P(t)=\sqrt{3} \eta_{i n v} V_{f n} I_{o} \cos \varphi
$$

Finally, the hybrid system energy conversion efficiency for harnessing energy from wind, solar and fuel cell is given by;

$$
\eta_{\text {sistema }}=\frac{P(t)}{P_{w t}+P_{p v}+P_{f c}}
$$

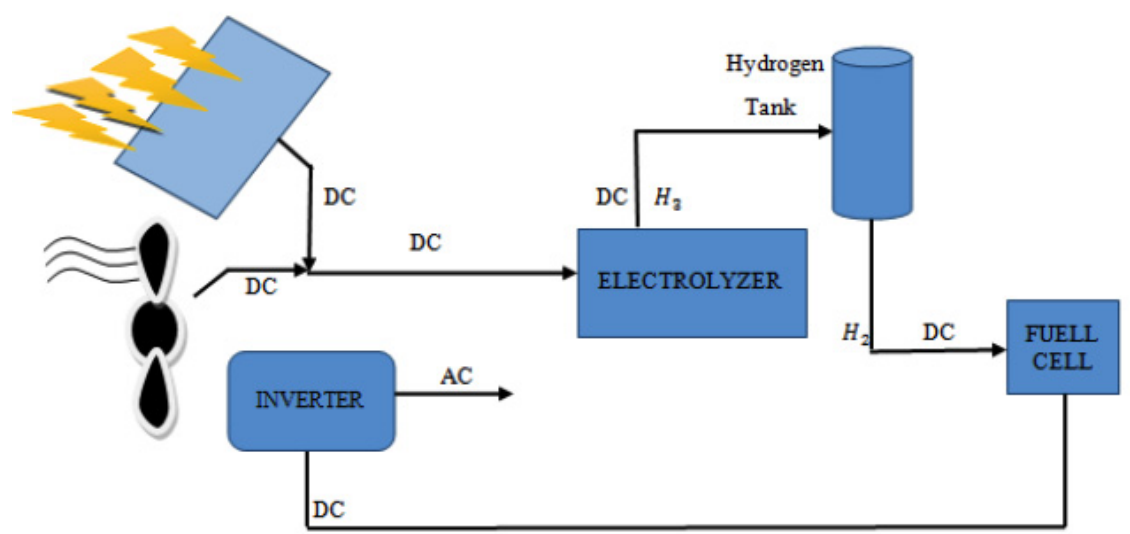

Figure 1: Hybrid Energy System Components.

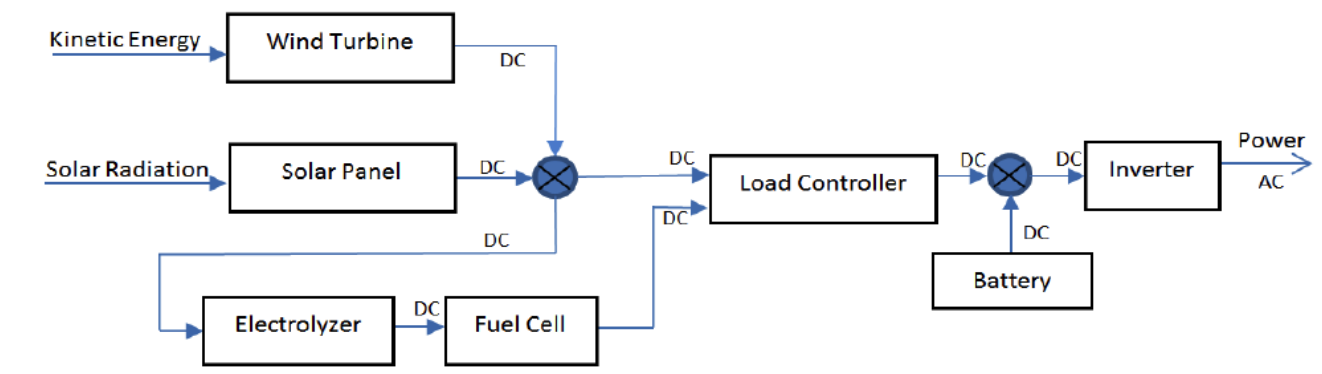

Figure 2: Hybrid Energy System including Fuel Cell.

\section{RESULTS AND DISCUSSION}

In order to solve the aforementioned equation (1) through (19) and taking into account that total power may not be simultaneous, and for validation purposes, this simulation model and the above mentioned equations were coded with MATLAB V13.2 and can be used as an optimization and design tool for hybrid systems. A block diagram approach was used during the simulation with MATLAB. In addition, for the purpose of validation and tuning up the predicted output simulated results, to this end the on-site data was used to validate the simulation program under various conditions. In the following sections, we present analysis and discussions of the numerical predicted results by MATLAB as well as validation of the proposed simulation model with experimental data.

\section{Components of Wind Hybrid System, PV and Fuel Cell}

The major components of the hybrid system are shown in Figure 1; photovoltaic, wind turbine and fuel cell power generation hybrid system generate as well as charge controller and battery. The battery stores excess power going through the load charge controller. The battery keeps voltage within the specified voltage and thus, protects over discharge rates, and prevent 
overload. To protect the battery against overload, the photovoltaic panel, wind generator and the fuel cell power output generator is disconnected from the system when the DC voltage increases above the current level required by the load. They are connected again when the DC bus voltage falls below the specified maximum voltage. To further protect the battery against excessive discharge, the load is disconnected when the DC bus voltage falls below minimum voltage as required by the load when the current is greater than the current generated by the solar panel, wind generator and fuel cell. The load is always connected when the DC bus voltage rises above minimum voltage. It is quite important to note that the inverter is employed to convert the DC power to $A C$ for $A C$ load as shown in Figure 2.

\section{Simplified Mathematical Model for wind Turbine Used in MATLAB}

Figure 3 displays the numerical iteration solution of the simulation model presented in equations (1) through (19) for lumped parameter model and taking into account that total power may not be simultaneous. Figure 3 also shows this simulation model and the above mentioned equations were coded with MATLAB V13.2. The numerical calculation procedure starts with the initiation of the independent and dependent parameters and solving the energy conversion

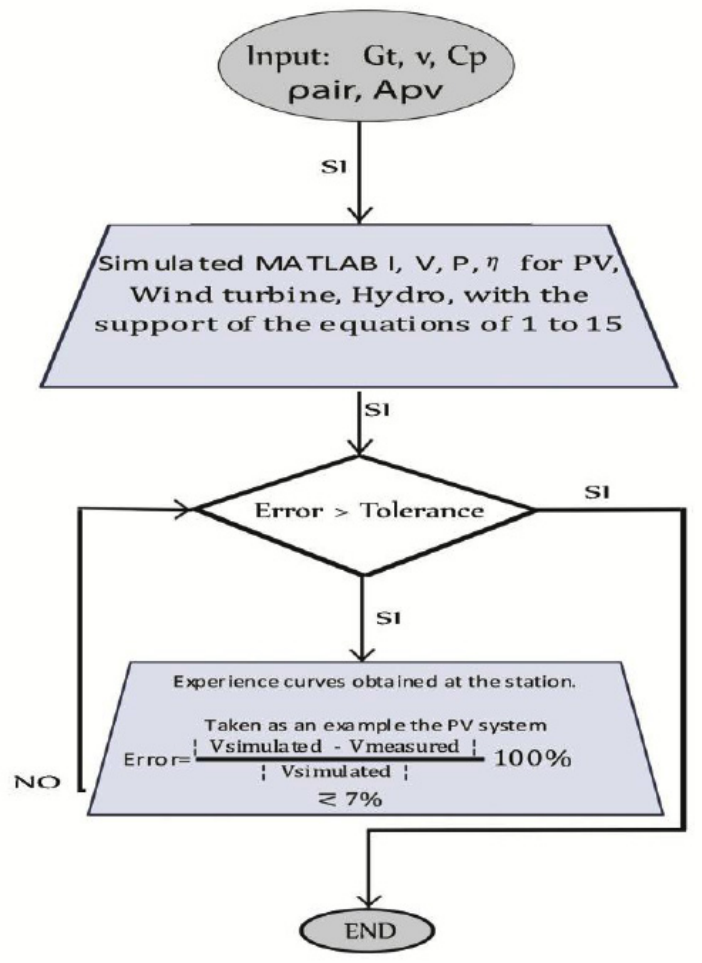

Figure 3: Numerical solution flow chart diagram. equations (10) through (19), to determine the hydrogen mass, hydrogen energy storage and electrical output from the fuel cell as well as the other components. The predicted results are printed once the iteration criteria were reached.

Figure 4 shows the general diagram representing the hybrid system in question where the output of the load controller is connected to an inverter where the direct current $C D$ is converted into alternate current $A C$ where power is supplied to the electric load.

In the Figure 5, a typical energy conversion sequence is presented for the input and output of a wind turbine system. Similarly, other energy conversion sequences can be established for the other systems such as solar photovoltaic and hydraulic power turbines using same conversion sequence. This link representation is a typical example of the simulation in MATLAB where the main features of the system are represented by block diagram. A simplified mathematical model with transfer functions used in MATLAB is shown in the Figure $\mathbf{5}$ for the wind turbine, where the controller and the inverter are to be integrated to predict the simulated behavior. Similar link representations were used in MATLAB for simulating the behavior of the solar and fuel cell, overall output power curves, and performance, as well as current and voltage; where; $\mathrm{K}$ is the coefficient proportional to input kinetic energy, $J$ represents inertia moment of the generator $\left[\mathrm{Kg}-\mathrm{m}^{2}\right]$, and $\mathrm{B}$ is the coefficient of friction of the generator $[\mathrm{N}-\mathrm{m} / \mathrm{rad} / \mathrm{s}], \mathrm{L}_{\mathrm{a}}[\mathrm{H}], \mathrm{R}_{\mathrm{a}}[\Omega]$ represents the inductance and resistance of the armature respectively, $\mathrm{Kp}$ is coefficient of the controller, $\mathrm{Td}$ is the time derivative of the controller, and $\mathrm{K}_{1}$ represents the constant of the inverter.

In the solar panels photovoltaic PV under investigation, the voltage of the solar panel is an input to the load controller and DC/AC inverter. The output of the inverter is maintained at constant 24 volts, thus the batteries are charged constantly with 24 Volts. With the help with inverter, the output $A C$ voltage is 120 volts depending upon the load. The PV solar two panels array has 240 watt output estimated at irradiance of $1000 \mathrm{w} / \mathrm{m}^{2}$ with an open circuit current of 15.14 ampere and open circuit volt of 21.7 Volts. The module efficiency and cell temperature are $12.1 \%$ and $25{ }^{\circ} \mathrm{C}$ respectively. The type of solar cell is mono-crystalline with $156 \times 156 \mathrm{~mm}$. each solar panel has 36 cells and size of the module is $1.482 \times 0.67 x .035$ meter.

The solar array output voltage and the amount generated by the solar array of photovoltaic are 


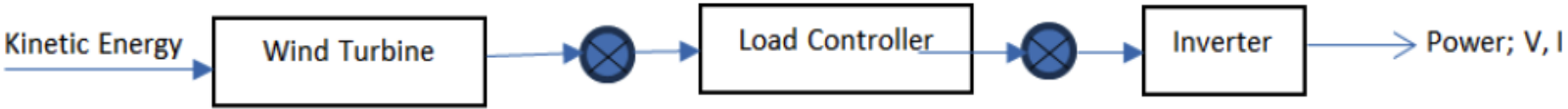

Figure 4: Typical block diagram for wind turbine.

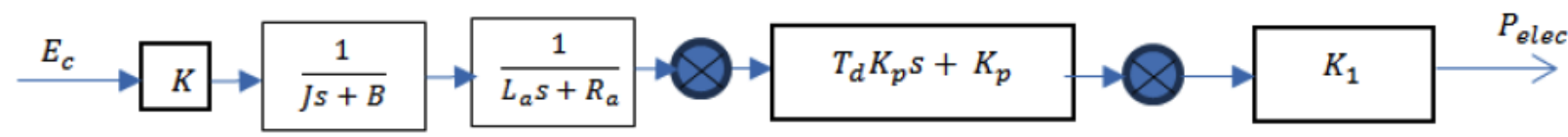

Figure 5: Block diagram representing parameters of the wind system in MATLAB.

variable since they depend upon not only on the sun irradiation, and temperatures but also on other parameters such as the voltage-current relation as well as the power-voltage relationship which are non-linear as depicted in Figures 6-8. In particular Figure 6 illustrates the basic concept of energy conversion from the solar insolation into electrical energy in terms of volts and amperes as shown at various values of solar irradiance. The results shown in Figures 6 and 7 clearly present the solar cell characteristics, and voltagecurrent characteristics as well as the voltage-power characteristics. Figure 8 has been constructed to show the energy conversion efficiency from irradiance to electrical energy. It is quite clear that higher irradiance will result in higher energy conversion efficiency. Therefore, the solar panels will be more efficient to operate at sites with higher irradiance.

The wind turbine considered in this study has the ability to adopt speed up to wind speed of $50 \mathrm{~m} / \mathrm{s}$ to achieve the maximum allowable power and if the wind speed is less than $2.5 \mathrm{~m} / \mathrm{s}$, no power is produced. The turbine rotor diameter is $3.2 \mathrm{~m}$ with three blades, the rated power and maximum power are $1.5 \mathrm{KW}$ and 1.8 $\mathrm{KW}$ respectively. Its rated wind speed is $9 \mathrm{~m} / \mathrm{s}$. The working voltage is $24 \mathrm{AC}$. The governing mechanical power delivered by wind turbine and its energy conversion efficiency are given equation (1 through 3 ), where it is a function of Betz power coefficient as well as other parameters. The power produced by the wind turbine is proportional to the wind speed, as the wind speed increases the power of the wind turbine increases. Figure 9 illustrates the impact of the Betz coefficient on the wind turbine power delivered. As shown at constant wind speed as the Betz coefficient is decreased less than 0.59 the power delivered is decreased. In addition, Figure 9 shows at constant Betz power coefficient, increasing the wind speed, results in increasing the power delivered by a wind turbine. Numerical simulations obtained by MATLAB indicate that the maximum power generated is at Betz power coefficient of 0.59 , however, beyond this point with increasing the wind speed the power generated decreases. The wind turbine under question operates at maximum capacity with Betz coefficient of 0.42 .

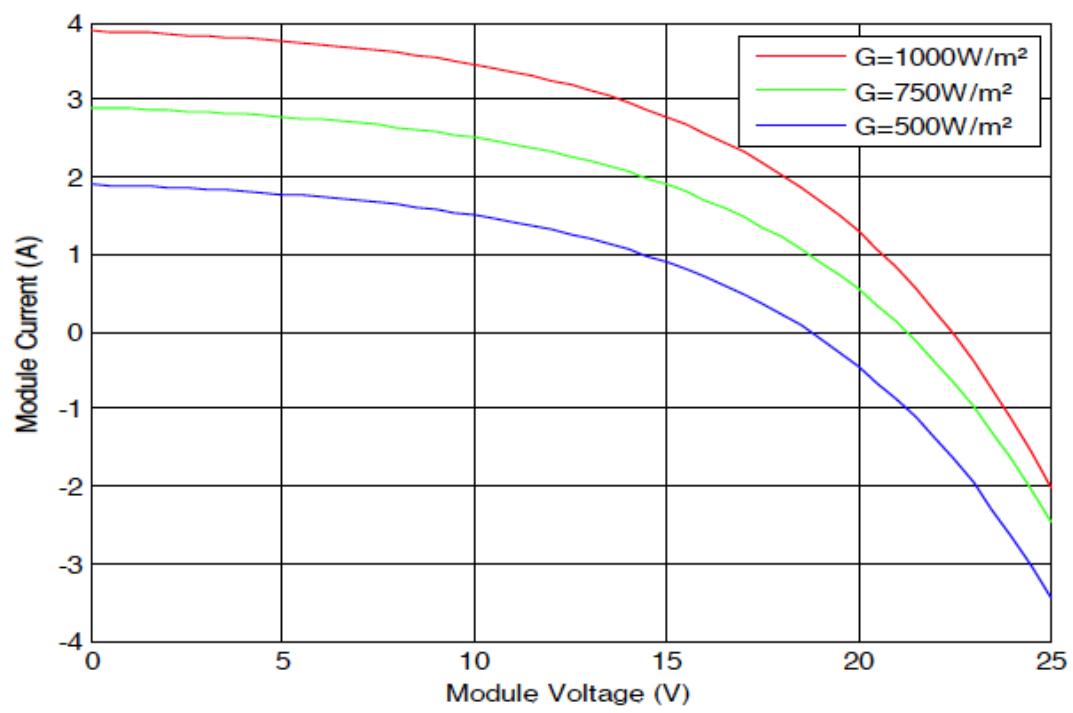

Figure 6: Voltage-Current curve for different values of irradiance- $\mathrm{W} / \mathrm{m}^{2}$. 


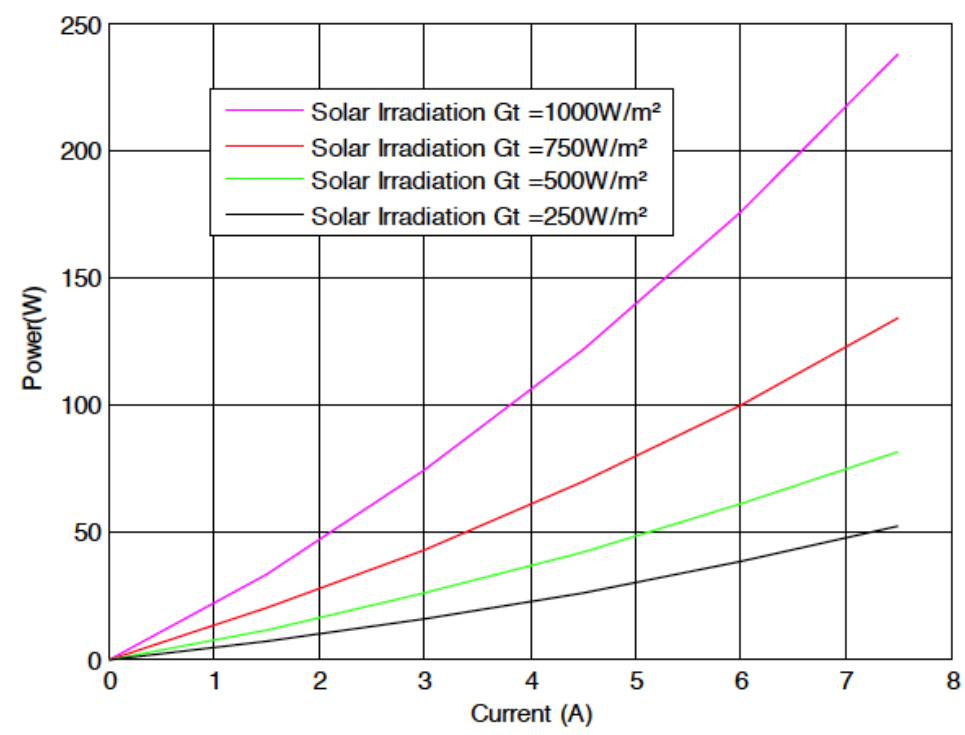

Figure 7: DC Current - DC Power PV for different values of $G\left(W / m^{2}\right)$.

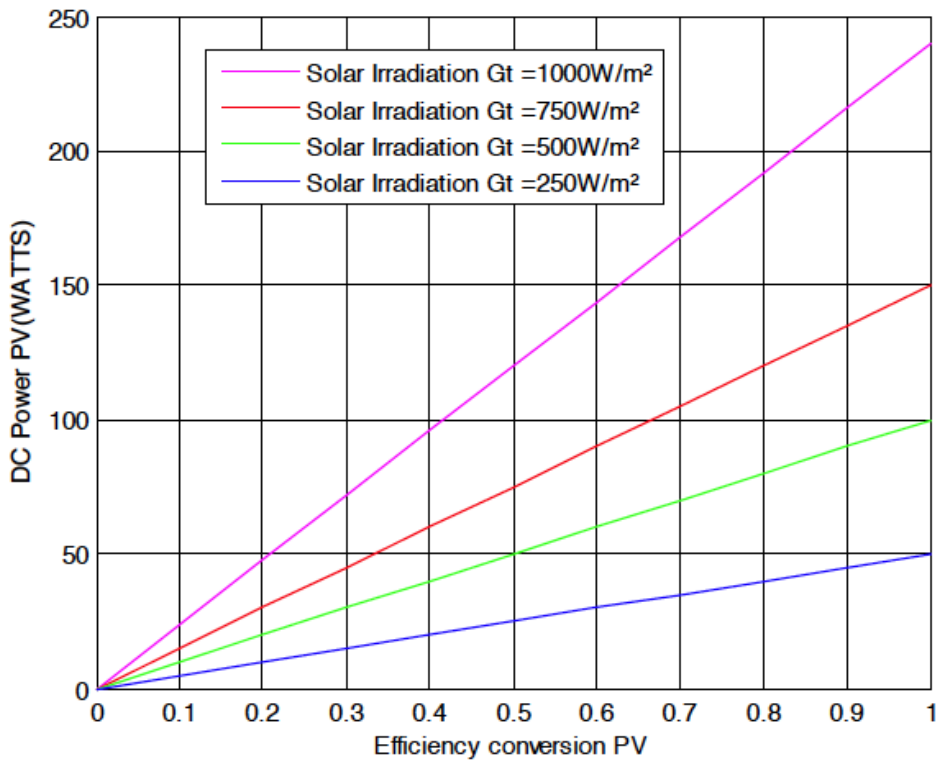

Figure 8: DC Power PV- Efficiency Conversion PV for different values of irradiance $\left(\mathrm{W} / \mathrm{m}^{2}\right)$.

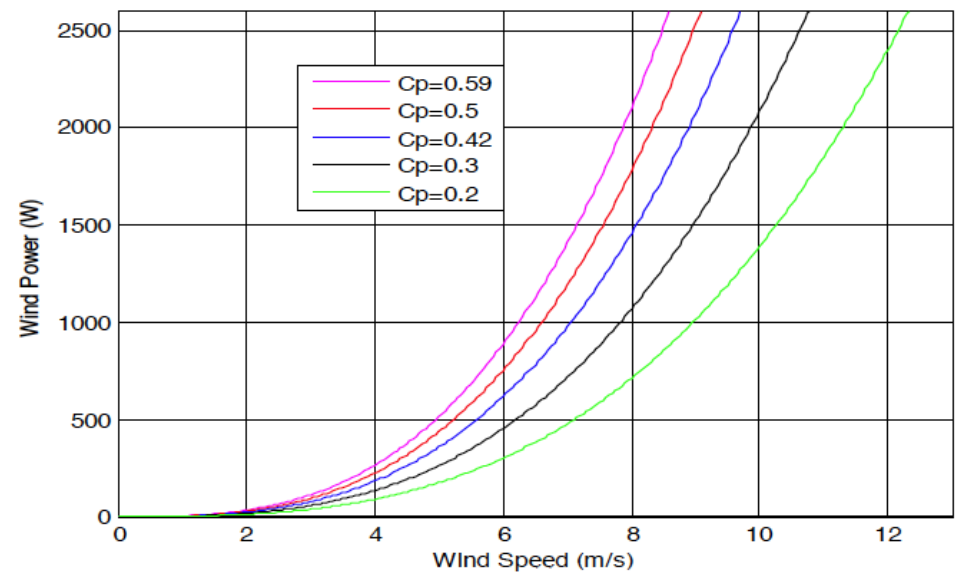

Figure 9: Power-speed curve for different values of Betz Coefficient. 


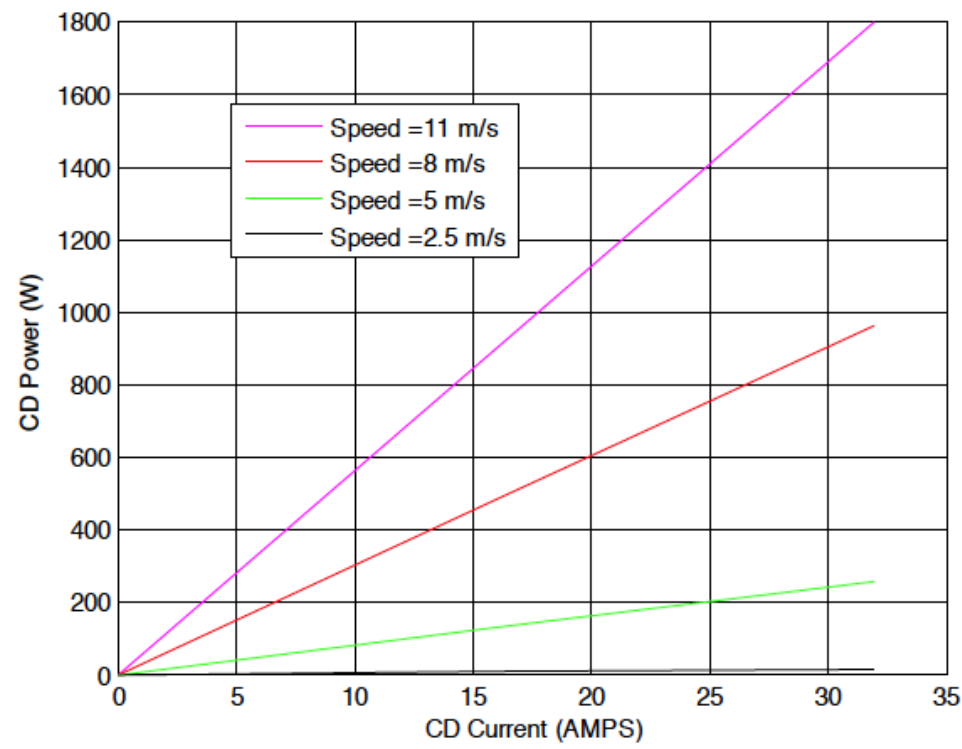

Figure 10: $C D$ Power- $C D$ Current curves for wind Speed $(\mathrm{m} / \mathrm{s})$.

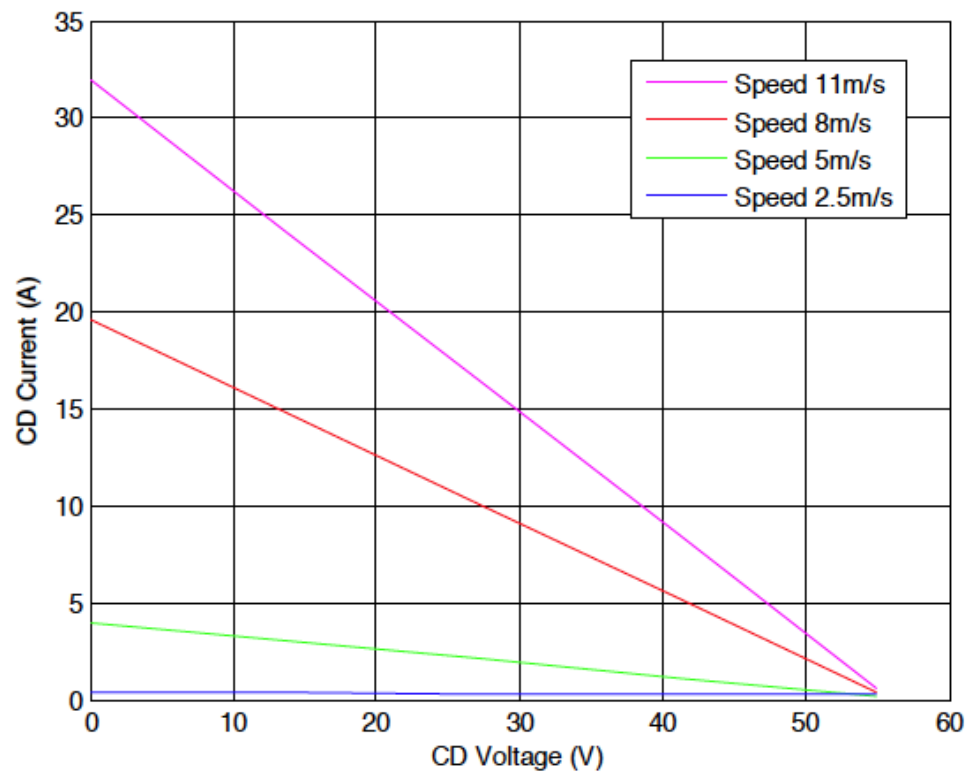

Figure 11: CD Current - CD Voltage curves for wind speed $(\mathrm{m} / \mathrm{s})$.

The impact wind speed on the electrical power output generated by the wind turbine has been illustrated in Figures 10 and 11. The predicted results displayed in these figures show that at the lower cut off speed of $2.5 \mathrm{~m} / \mathrm{s}$ and higher cut off speed $11 \mathrm{~m} / \mathrm{s}$, the wind electrical power generated is 50 and 1800 Watts which coincide with the wind turbine specifications provided by the manufacturer. Furthermore, Figure 12 has been constructed to show the impact of the wind speed on the energy conversion efficiency form wind energy to electrical energy. It is quite clear that the higher wind speed results in higher energy conversion efficiency and produces more power output. However, for the wind turbine under investigation, the minimum starting wind speed is $2.5 \mathrm{~m} / \mathrm{s}$, at this particular condition, the power output and conversion efficiency are significantly low and economically viable.

A part of the energy provided by the solar panels photovoltaic and wind turbine is used to drive the electrolyzer and result in storing the hydrogen as shown in Figures $\mathbf{1}$ and $\mathbf{2}$. The electrolyzer is composed of a number of isolated cells from each other in a separate stack. Cell operating voltage at normal conditions is $1.7-1.9 \mathrm{~V}$ and the operating temperature does not exceed $70{ }^{\circ} \mathrm{C}$ [10]. As shown in Figures 1 and $\mathbf{2}$ the hydrogen leaving the electrolyzer is directed towards the fuel cell. The fuel cell uses 


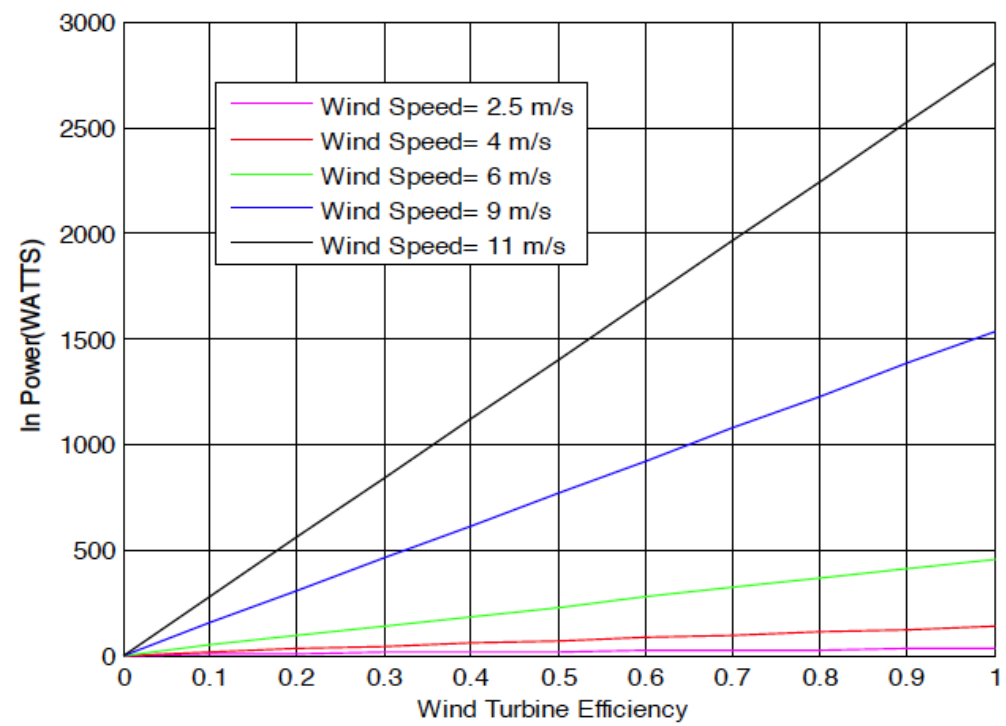

Figure 12: Energy conversion efficiency at various wind speeds.

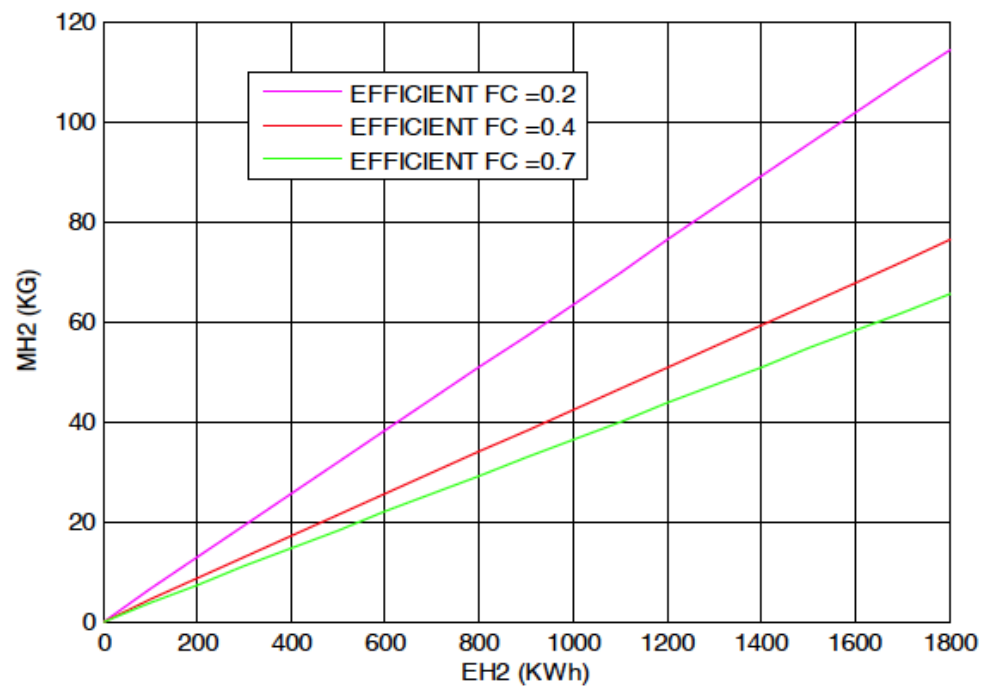

Figure 13: Fuel Cell Hydrogen Mass at Different Energy stored in form of Hydrogen and fuel cell efficiencies.

hydrogen to produce electricity. The performance of the PEMFC is based upon the voltage produced as the current increases. Theoretically, the ideal voltage of the fuel cell is the Nernst potential, however as indicated in equation (13), however, with external circuit there are three voltages losses involved in the fuel cell voltage output; activation voltage, ohmic voltage and concentration voltage [7]. The fuel cell under consideration in this study is of type Proton Exchange Membrane Fuel Cell PEMFC [7, 10]. The various terms in equation (13) represents the voltage difference between the cell terminals, are generated by the movement of electrons through the external circuit and proton through the membrane for a single cell. This voltage difference was numerically calculated using the theoretical model of a proton exchange membrane
(PEM) fuel cell model reported by Najafizadegan and Zarabadipour [14]. Furthermore, Lin et al. [15] presented extremely valuable data used in the numerical model to calculate and validate model as well as the various terms of equation (13) to predict the voltage difference between the cell terminals. It is worthwhile mentioning that the first, second and third terms of equation (13) have functional dependence on the operating temperature of the fuel cell. Furthermore, the fourth term is mainly due to the reactive excess near the catalyst surface and is a function of the current density passing through the cell at each moment.

The fuel cell considered for this simulation, has number of cells; 33 , operating temperature; $338^{\circ} \mathrm{K}$, cell 
active area; $40.6 \mathrm{~cm}^{2}$, membrane thickness; $178 \mu \mathrm{m}$, current density; $1.42 \mathrm{~A} / \mathrm{cm}^{2}$ and partial pressures of hydrogen and oxygen are $3 \mathrm{~atm}$ and 1 atm, respectively. It was assumed in this simulation model that $\eta_{c}=1 . \gamma=1.41, P_{e}=10^{5} \mathrm{~Pa}$ and $V_{o}=11.11 \mathrm{~m}^{3} / \mathrm{kg}$ of hydrogen. Figure 13 shows the simulation results of the fuel cell in question predicted by the numerical model (equations (7) through (12)). The energy storage of hydrogen for different hydrogen mass was plotted at various fuel cell efficiencies. It is quite clear that the higher the fuel cell efficiency the maximum energy storage of hydrogen with small hydrogen mass that leads to higher fuel cell power output. The storage of hydrogen has significant value in supplying continuous power at periods of low wind speeds and solar irradiance. In addition, it can be used as a source of power and electrification of remote areas disconnected from the grid.

It is quite desirable to produce more fuel cell output with less hydrogen mass. Therefore the storage capacity is reduced. The compressor energy needed to store the hydrogen mass is plotted in Figure $\mathbf{1 4}$ against the hydrogen mass for various compression pressure

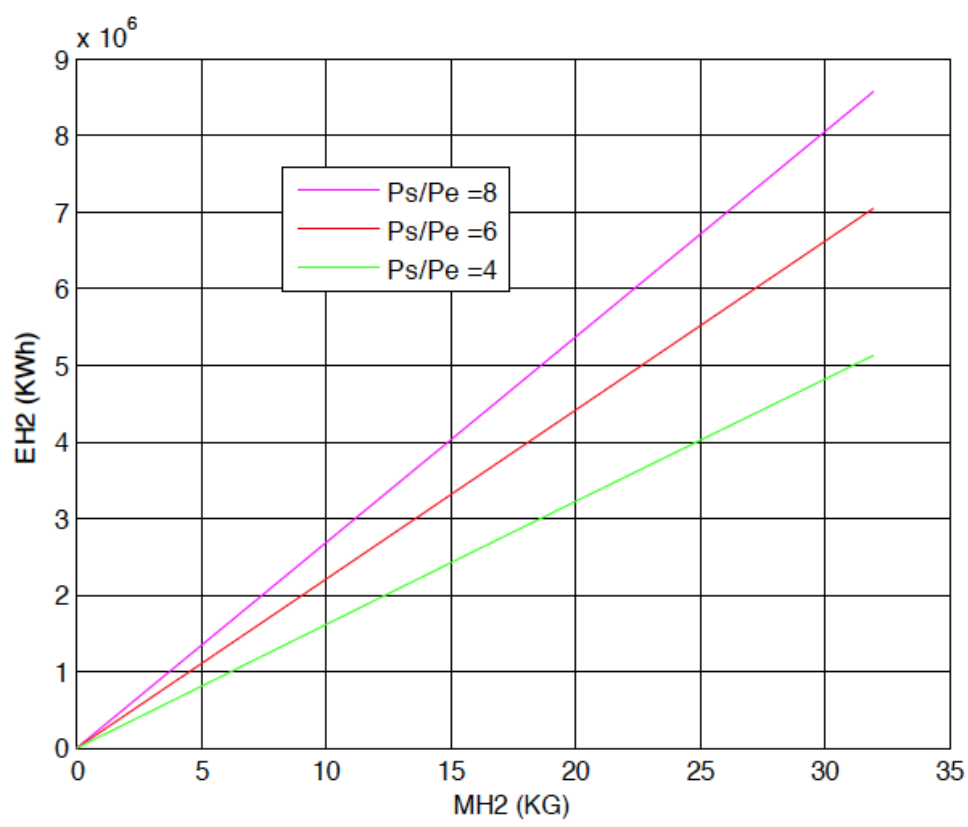

Figure 14: Energy stored in form of Hydrogen at different compression pressure ratio.

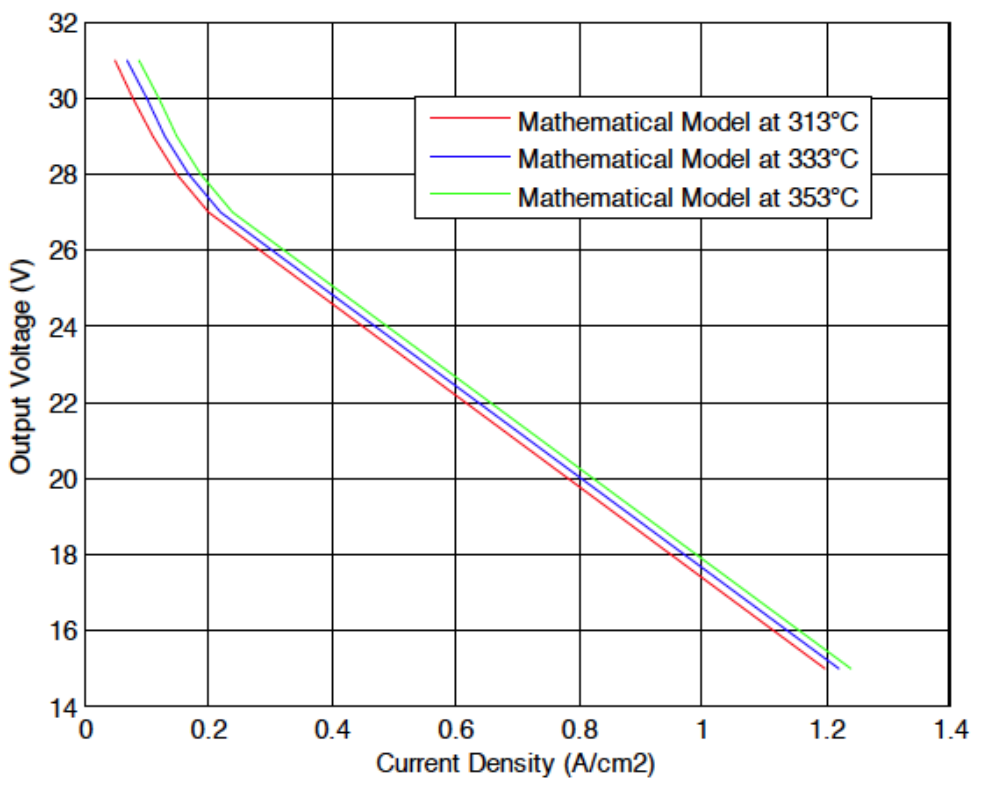

Figure 15: Output Voltage and amperage of fuel cell at different operating temperatures. 
ratios. It is obvious from equation (11) and simulation results presented in Figure $\mathbf{1 4}$ that more energy compression is required at higher pressure ratios.

As discussed in the aforementioned sections, the first, second and third terms of equation (13) have functional dependence on the operating temperature of the fuel cell. Therefore, Figure $\mathbf{1 5}$ has been constructed to study the impact of the operating temperature of the fuel cell on the output voltage and current density under three different temperatures; 313,333 , and 353 $\mathrm{K}$. It is quite clear from the simulated results, that at a constant voltage, the higher the operating temperature the more current is delivered and obviously more power supplied. However, the simulated results also show that the impact of operating temperature is minimum. It is also worthwhile mentioning that the results presented in Figure $\mathbf{1 5}$ are consistent with data reported by other references namely Mahalakshmi and Latha [7].

The simulated results of the fuel cell efficiency at various input power for various wind turbine speeds, are presented in Figure 16 for a load of $5 \mathrm{KW}$ and typical irradiance of $160 \mathrm{kwh} / \mathrm{m}^{2}$. It is assumed that available input power is from wind turbine and photovoltaic in this hybrid system as shown in Figures 1 and 2. It is quite evident from the results in this figure that increasing the wind speed will result in lowering fuel cell efficiency. To enhance the fuel cell efficiency, one must increase the load proportionally to the input power to drive the fuel cell. It is worthwhile mentioning that it was assumed in this simulation that $70 \%$ of the load is provided by the fuel cell based upon an electrolyzer efficiency of $40 \%$ and compression efficiency of $100 \%$.

Finally, the energy conversion efficiency of the hybrid system in question including the wind turbine, photovoltaic, electrolyzer, and hydrogen compression as well as fuel cell has been predicted for the hybrid system shown in Figures 1 and 2 . The results of the simulation were presented and plotted in Figure 17 against output power at a typical irradiance of 160 $\mathrm{kwhr} / \mathrm{m} 2$. The impact of hydrogen storage has been discussed in the aforementioned sections. The simulated results show that higher output power enhances the hybrid system efficiency.

Obviously, the hybrid system energy conversion efficiency will be affected by the solar irradiance. The results presented in Figure $\mathbf{1 7}$ are consistent with others reported in the literature namely reference [23].

Furthermore, Figure 18 has been constructed to display the hybrid system efficiency at various irradiance and minimum wind velocity $2.5 \mathrm{~m} / \mathrm{s}$ needed to drive the wind turbine under study. It has been observed from this figure that the higher the irradiance the lower the hybrid system efficiency since the load remains constant. As discussed in the aforementioned section, in order to enhance the hybrid system efficiency the load has to be increased proposionaly with the increase of either the wind speed and or the irradiance. In other words, the hybrid system has to be designed to match the load in order to operate at higher efficiency.

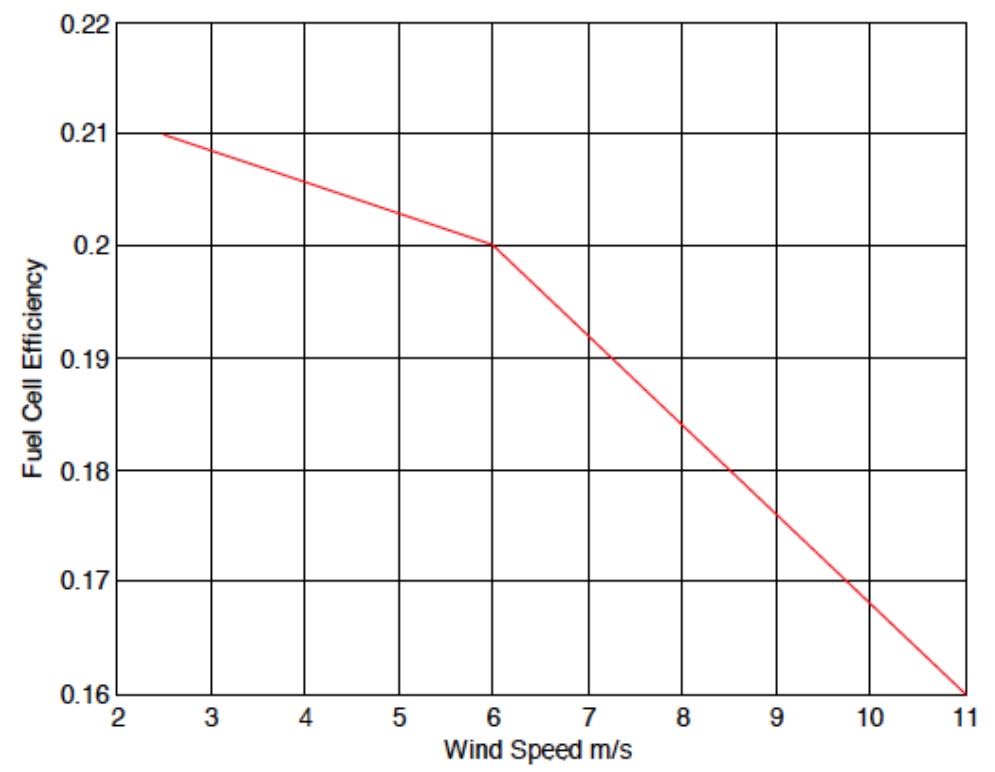

Figure 16: Fuel cell energy conversion efficiency. 


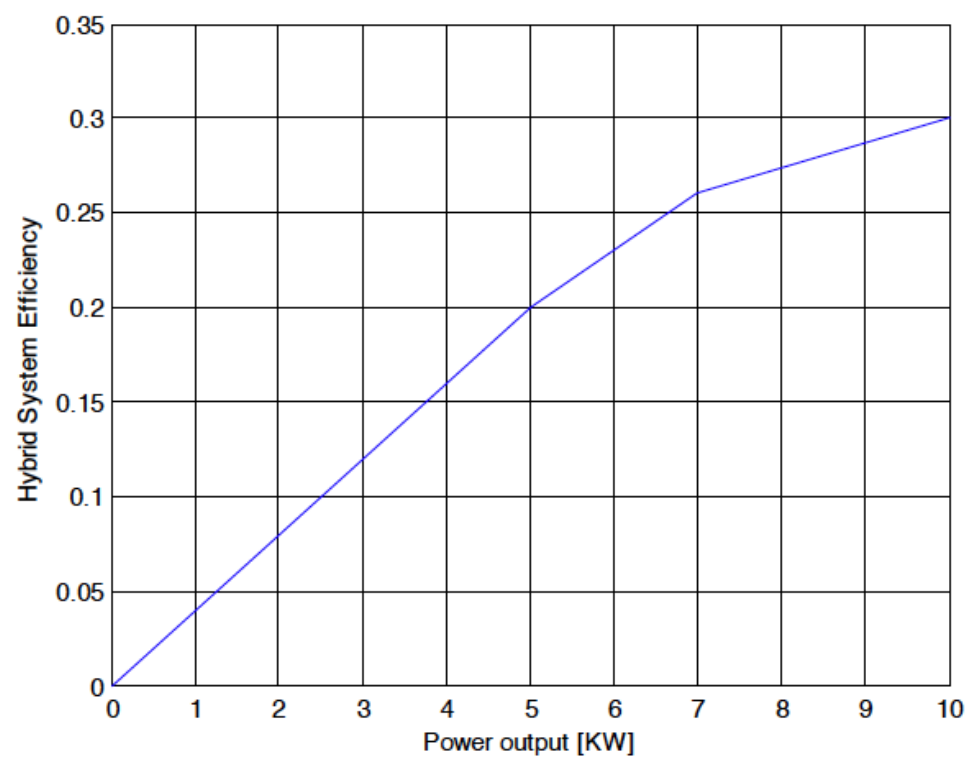

Figure 17: Hybrid System energy conversion efficiency at typical irradiance of $160 \mathrm{kwh} / \mathrm{m}^{2}$.

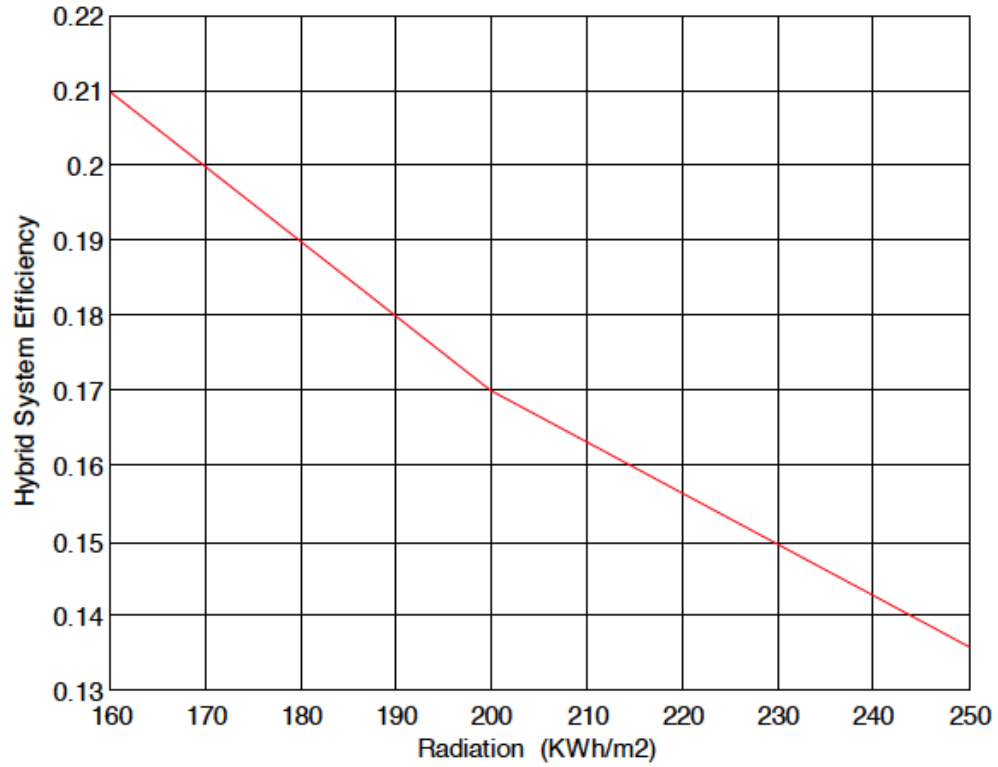

Figure 18: Hybrid System energy conversion efficiency at typical wind speed $2.5 \mathrm{~m} / \mathrm{s}$.

\section{Simulation Model Validation}

In order to validate the prediction of our numerical model described in equations (1through 19), we have constructed Figures 19 and 23. After analyzing the wind speed data in the site where the environmental station was installed, it was concluded that the data are not consistent and could not be used to validate the model. Therefore, the experimental data presented by references [11] through [13] were used for validation purposes. Figures 19 and 20 have been constructed where the predicted outputs of the wind turbine are depicted under various wind speed and RPM of the turbine shaft against the experimental data.
It is quite apparent from these figures that our numerical model fairly predicted the wind turbine output. However, analyzing Figure 19 points out that our model predicted very well the wind power data up to wind speed of $5.5 \mathrm{~m} / \mathrm{s}$ and beyond that point there was some discrepancies between the model prediction and the data. We believe that these discrepancies are due to variable Betz coefficient $\mathrm{Cp}$ and kinetic and mechanical losses at higher wind speeds. In addition, since our model assume a constant Betz coefficient, our model could not take into account the mechanical and kinetic losses encountered at high speed. 


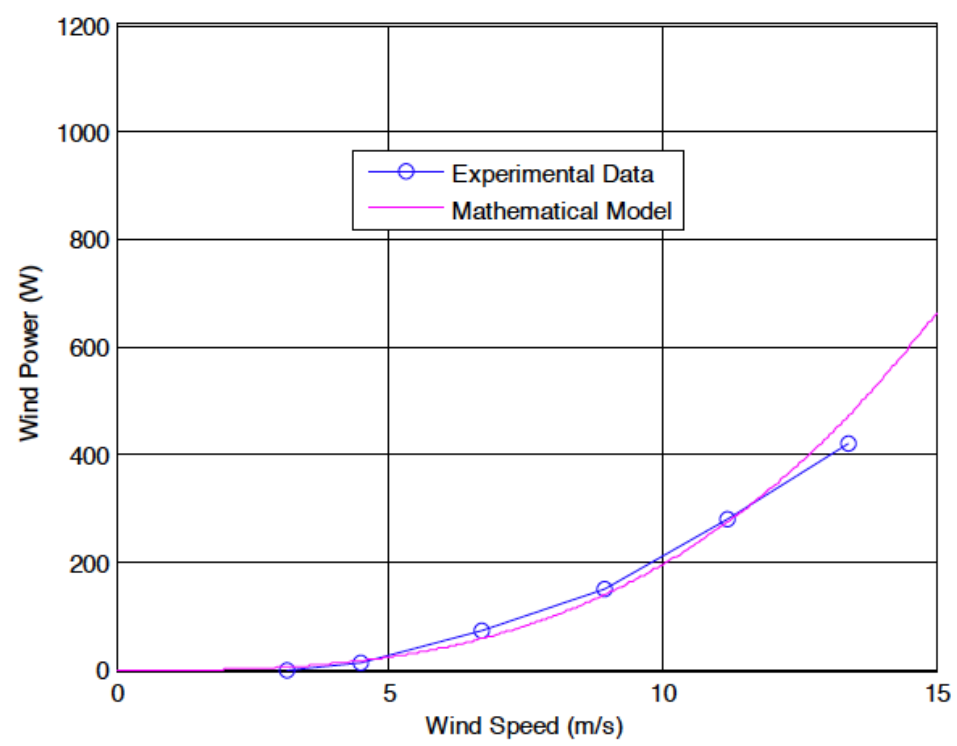

Figure 19: Comparison between Wind Turbine data (Ikhsan et al. [18]) and model prediction.

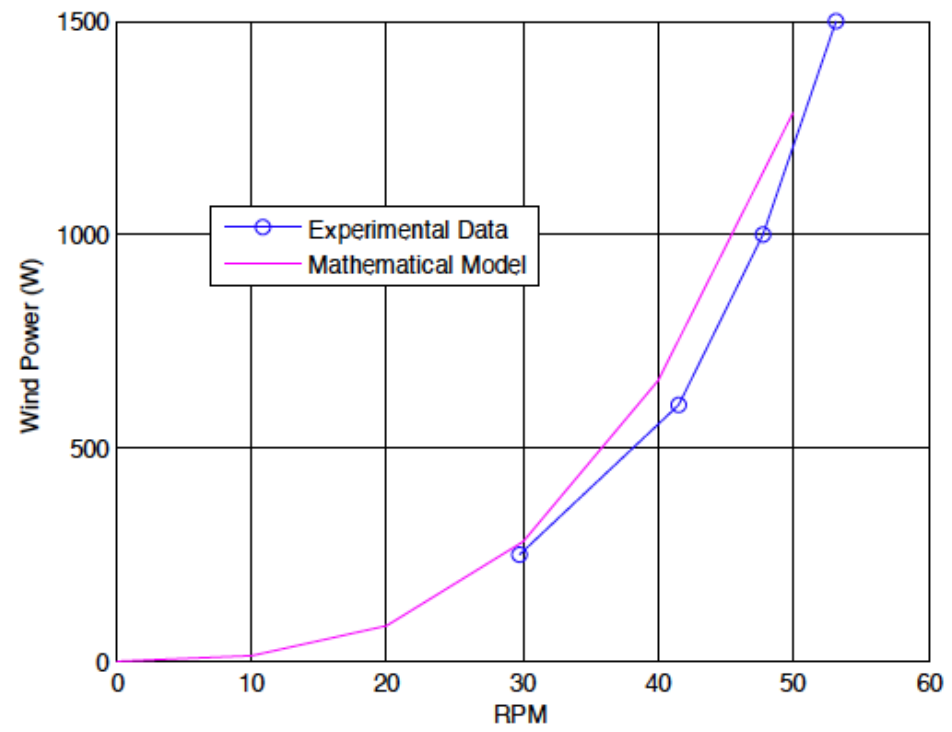

Figure 20: Comparison between Wind Turbine data ([19] and Bosma B. and Kallio [20]) and model prediction.

Furthermore, the wind turbine data presented by ([12] and Bosma B. and Kallio [20]) were displayed, simulated and compared to our numerical model's prediction at different RPM in Figure 20. It is quite evident that our numerical model predicted well the wind turbine data at various RPM.

In order to validate our model's prediction of solar panels and since the irradiance data at the University site was not consistent, we have opted to use the solar radiation data presented by Benghanem and Alamri [21]. Figure 21 displays the model prediction of this data in terms of electrical power voltage and amperage and compares against the data of reference [21]. It is quite evident from the data presented in this figure that the numerical model predicted the data very well between output voltages of 9 through 20 volts. However, data less than 9 volts showed constant current values at different voltages. Therefore, outputs under 9 voltages were under predicted. It is in our opinion that the model under predicted the data because of the energy conversion efficiency was not consistent at low voltage. In additions, details of measurements of the voltage and amperage were not fully disclosed in reference [21].

In another attempt to validate the numerical model, a comparison between the experimental Data [22] and the mathematical model prediction at $750 \mathrm{~W} / \mathrm{m}^{2}$ has been demonstrated in Figure 22. Clearly this figure 


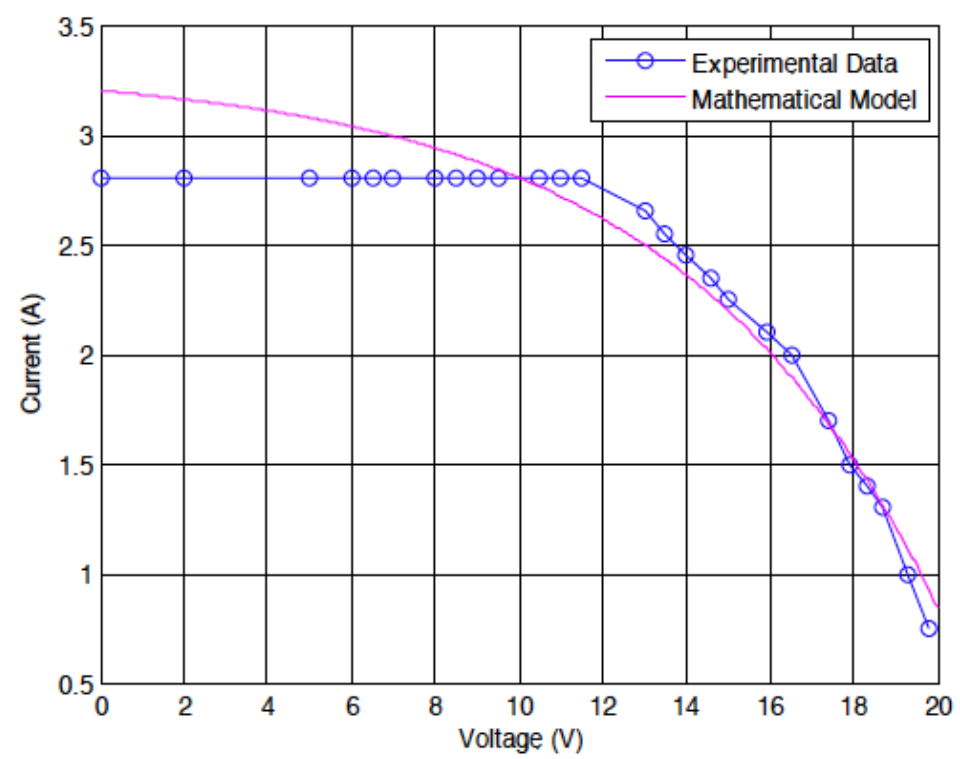

Figure 21: PV output data [21] compared to model prediction.

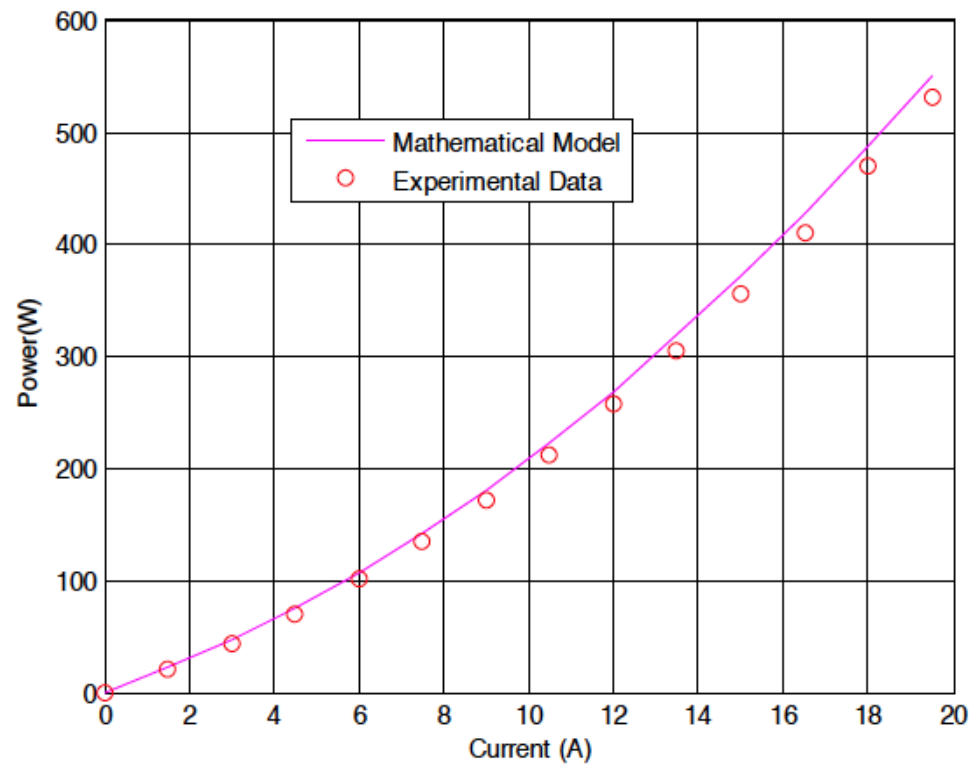

Figure 22: Comparison of Current - Power Experimental Data [22] and Mathematical Model at $750 \mathrm{~W} / \mathrm{m}^{2}$.

shows that the model well predicted the data of Ramon et al. [22].

Simulation results of the fuel cell performance have been compared with the data of Lin et al. [15] and presented in Figure $\mathbf{2 3}$ for fuel cell operating temperature $18{ }^{\circ} \mathrm{C}$ and $80{ }^{\circ} \mathrm{C}$, respectively for fuel cell voltage and current density. It is quite evident from this figure that our proposed numerical model fairly predicted the fuel cell data at temperatures $80^{\circ} \mathrm{C}$ and $18{ }^{\circ} \mathrm{C}$. However, the figure shows the fuel cell data were under predicted and some discrepancies existed with the data prediction at temperature of $18{ }^{\circ} \mathrm{C}$ and in particular at current density higher than $800 \mathrm{~mA} / \mathrm{cm}^{2}$.
We feel that these minor discrepancies might be due to the initial conditions and parameters used in the simulation $[10,15]$ at the lower temperatures. It is also worthwhile mentioning that Lin et al. [15] did not provide a full disclosure of his experimental data initial conditions and parameters, therefore; we attribute these minor discrepancies to the choice of some initial parameters used in the simulation.

\section{CONCLUSIONS}

The energy conversion equations describing the total power generated by a hybrid system of solar photovoltaic, wind turbine and fuel cell including 


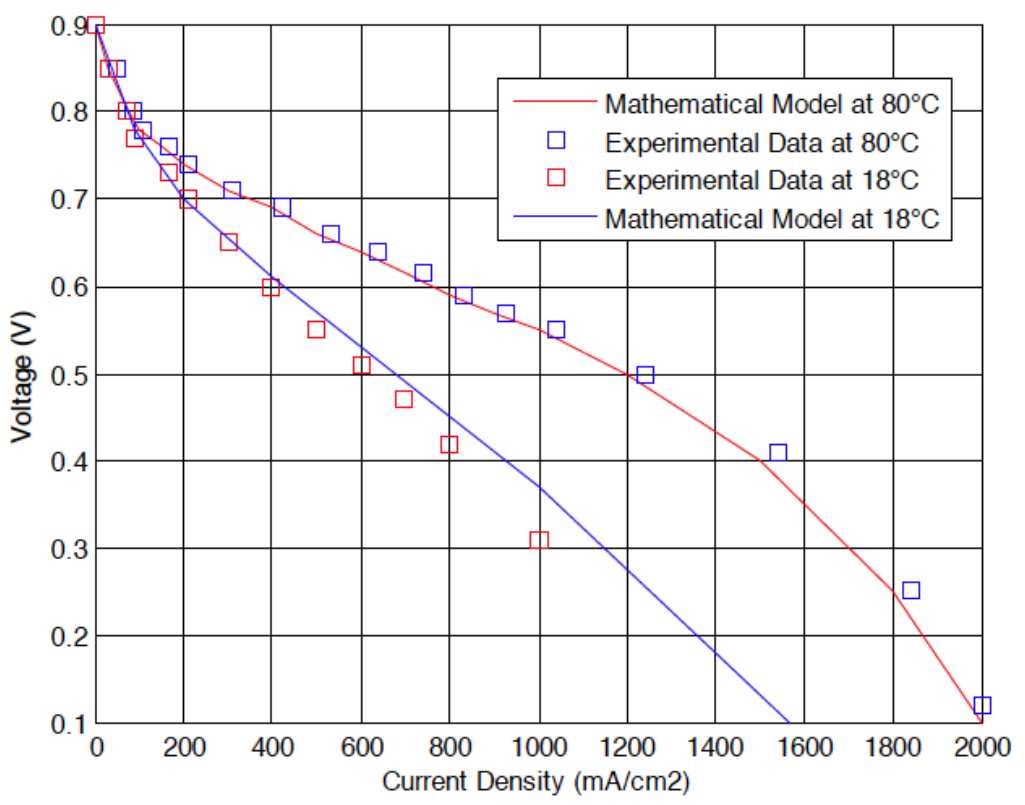

Figure 23: Comparison of between the predicted results of fuel cell output and data at $80^{\circ} \mathrm{C}$ [15].

hydrogen storage were presented, and integrated simultaneously. In addition, expressions for energy conversion efficiencies were also developed and presented. For the purpose of validating this simulation model, the aforementioned equations were coded with MATLAB V13.2 and can be used as an optimization and design tool. A block diagram approach was used during the simulation with MATLAB. Comparison between the model predictions and the on-site data showed that the model well predicted the data under various conditions.

\section{NOMENCLATURE}

\begin{tabular}{|c|c|c|}
\hline$A_{p v g}$ & $=$ & PV solar collector area $\left(\mathrm{m}^{2}\right)$ \\
\hline$B$ & $=$ & $\begin{array}{l}\text { Coefficient of friction of the generator } \\
\text { referred at wind turbine }[\mathrm{N}-\mathrm{m} / \mathrm{rad} / \mathrm{s}]\end{array}$ \\
\hline $\cos \varphi$ & $=$ & Power factor referred to wind turbine \\
\hline$C_{p}$ & $=$ & Betz power coefficient \\
\hline $\mathrm{C}_{\text {compressor }}$ & $=$ & Compressor energy \\
\hline $\mathrm{E}_{\mathrm{H} 2}$ & $=$ & ydrogen energy \\
\hline $\mathrm{G}_{\mathrm{t}}$ & $=$ & Solar irradiation $\left(\mathrm{W} / \mathrm{m}^{2}\right)$ \\
\hline$I_{0}$ & $=$ & Single-phase current \\
\hline$l_{e}$ & - & Current between electrodes \\
\hline$I_{\text {line }}$ & $=$ & Line current referred to wind turbine \\
\hline
\end{tabular}
$I_{P V}(t) \quad=$ Current referred to PV in DC
$I_{\text {rect }}=\mathrm{DC}$ current to the rectifier output
$\mathrm{J}=\quad=$ Inertia moment of the generator $\left[\mathrm{Kg}-\mathrm{m}^{2}\right]$
$\mathrm{K}=$ Coefficient proportional to input kinetic energy
$\mathrm{K}_{1}=$ Constant of the inverter
$\mathrm{Kp}=$ Coefficient of the controller
LLP $=$ Loss of load probability
$\mathrm{L}_{\mathrm{a}} \quad=$ Inductance of armature $[\mathrm{H}]$
$\mathrm{M}_{\mathrm{H} 2} \quad=$ Mass of hydrogen
$N_{S B a t}=$ Number of batteries connected in series
$\mathrm{P} \quad=$ Pressure
$\mathrm{P}(\mathrm{t}) \quad=\mathrm{AC}$ power of the inverter output
$P_{3 f}=$ Three phase $\mathrm{AC}$ power of the wind turbine
$P_{W T} \quad=$ Wind power sweep produced by the blades
$P_{p v} \quad=\quad$ Nominal Power PV
$P_{P V}(t)=$ Electrical power DC of PV
$P_{\text {cont-dc }}=$ Power Controller 


$\begin{array}{ll}P_{\text {inv-ip }} & =\text { Inverter input power } \\ P_{\text {inv-op }} & =\text { Inverter output power } \\ \mathrm{R} & =\text { Gas constant } \\ \mathrm{R}_{\mathrm{a}} & =\text { Resistance of armature }[\Omega] \\ \mathrm{RPM} & =\text { Revolutions per minutes } \\ \mathrm{T} & =\text { Temperature } \\ T_{c} & =\text { The collector temperature } \\ T_{c \text { ref }} & =\text { The collector reference temperature } \\ \mathrm{Td} & =\text { Time derivative of the controller } \\ U_{\text {line }} & =\text { Line voltage referred to wind turbine } \\ V & =\text { Wind velocity } \\ V_{P V}(t) & =\text { Voltage referred to PV in DC } \\ V_{b a t} & =\text { Nominal voltage DC in the battery } \\ V_{f n} & =\text { Phase- neutral voltage } \\ V_{s t a c k} & =\text { Fuel cell Stack voltage } \\ \mathrm{X}_{\mathrm{H}} & =\text { Hydrogen production rate }\end{array}$

\section{Greek Alphabet}

$\beta=$ Temperature coefficient $((0.004-0.006)$ per $\left.{ }^{\circ} \mathrm{C}\right)$

$\eta_{\text {aer }}=$ Wind turbine efficiency

$\eta_{\text {fmec }}=$ Mechanical friction efficiency

$\eta_{g} \quad=$ Generator machine efficiency

$\eta_{m p} \quad=$ Speed multiplication box efficiency

$\eta_{c 1}=$ Electric conversion efficiency is referred to wind turbine

$\eta_{p v g} \quad=\quad \mathrm{PV}$ solar collector efficiency

$\eta_{p c} \quad=$ power conditioning efficiency

$\eta_{r} \quad=$ The reference module efficiency

$\eta_{c 2}=$ The efficiency of conversion to DC referred to PV

$\eta_{\text {acc }}=$ The losses efficiency

$$
\begin{array}{ll}
\eta_{\text {inv }} & =\text { Inverter efficiency } \\
\eta_{\text {sistem }} & =\text { Hybrid system efficiency } \\
\rho_{\text {air }} & =\text { Air density }
\end{array}
$$

\section{Subscripts}

$$
\begin{aligned}
& \text { aer }=\text { Aero generator } \\
& \text { Air } \quad=\text { Air } \\
& \text { acc }=\text { Accessories } \\
& \text { bat }=\text { Battery } \\
& \text { Cont-dc = Controller } \\
& c 1=\text { Electric conversion referred to wind } \\
& \text { turbine } \\
& \text { c2 }=\text { Conversion to } \mathrm{DC} \text { referred to } \mathrm{PV} \\
& \text { fn } \quad=\text { Phase neutral } \\
& \text { fmec }=\text { Mechanical friction } \\
& \text { FC }=\text { Fuel cell } \\
& \text { inv-ip = Inverter input } \\
& \text { inv-op = Inverter output } \\
& m p=\text { Multiplication box } \\
& \mathrm{p}=\text { Power } \\
& \text { pc } \quad=\text { Power conditioning } \\
& \text { PV = Photo Voltaic } \\
& \text { pvg } \quad=\text { Irradiance PV } \\
& \text { rect } \quad=\text { Rectifier } \\
& \text { SBat }=\text { Batteries connected in series } \\
& \text { total }=\text { Total } \\
& W T \quad=\text { Wind Turbine } \\
& 3 f=\text { Three phase } \mathrm{AC}
\end{aligned}
$$

\section{ACKNOWLEDGEMENT}

The research work presented in this paper was made possible through the support of the Catholic University of Cuenca. 


\section{REFERENCES}

[1] Department of Energy, Potential benefits of distributed generation and rate related issues that may impede their expansion, A Study Pursuant to Section 1817 of the Energy Policy Act of 2005" 2007.

[2] Binayak B, Shiva RP, Kyung-Tae L, Sung-Hoon A. Mathematical modeling of hybrid renewable energy System: a review on small hydro-solar-wind power generation. International Journal of Precision engineering and Manufacturing-green Technology 2014; 1(2): 157-173.

[3] Kavitha S, Kamdi SY. Solar hydro hybrid energy system simulation. International Journal of Soft Computing and Engineering (IJSCE) 2013; 2(6): 500-503.

[4] Nema P, Nema RK, Rangnekar S. A review current and future state of art development of hybrid system using wind and PV-solar: a review. Renewable and Sustainable Energy Reviews 2009; 8(13): 2096-2103. http://dx.doi.org/10.1016/j.rser.2008.10.006

[5] Akikur RK, Saidur R, Ping H, Ullah KR. Comparative study of stand-alone and hybrid solar energy systems suitable for offgrid rural electrification: A review. Renewable and Sustainable Energy Reviews 2013; 27: 738-752. http://dx.doi.org/10.1016/j.rser.2013.06.043

[6] Bhandari B. Design and evaluation of tri-hybrid renewable system (THRES), Ph. D. Thesis 2014; Department of Mechanical \& Aerospace Engineering, Seoul National University.

[7] Mahalakshmi M, Latha S. Modeling and simulation and sizing of photovoltaic/wind/fuel cell hybrid generation system. International Journal of Engineering Science and Technology, IJEST 2012; 4(5).

[8] Maharia VK, Dalal G. Hybrid PV/fuel cell system design and simulation. International Journal of Science and Research, IJSR 2014; 3(9).

[9] Kumar S, Garg V. Hybrid system of PV solar/wind \& fuel cell, International Journal of Advanced Research in Electrical. Electronics Instrumentation Engineering, IJAREEIE 2013; 2(8).

[10] Touanti S, Belkaid A, Benabid R, Halbaoui K, Chelali M. Prefeasibility design and simulation of hybrid PV/fuel cell energy system for application to desalination plants loads. Procedia Engineering 2012; 33: 366-376. http://dx.doi.org/10.1016/j.proeng.2012.01.1216

[11] Saha NC, Acharjee S, Mollah MAS, Rahman KT, Rafi FHM. Modeling and performance analysis of a hybrid power system. Proc. of International Conference on Informatics Electronics \& Vision (ICIEV) 2013; pp. 1-5. http://dx.doi.org/10.1109/iciev.2013.6572669
Mustafa E. Sizing and simulation of PV-wind hybrid power system. International Journal of Photoenergy 2013; 2013: Article ID 217526, 10 pages, 2013.

[13] Saib S, Gherbi A. Modeling and simulation of hybrid systems (PV/wind/battery) connected to the grid. International Conference on Electrical Engineering and Automatic Control, 2013; Setif, 24-26 November

[14] Najafizadegan $H$, Zarabadipour $H$. Control of voltage in proton exchange membrane fuel cell using model reference control approach. International Journal of Electochemical Science 2012; 7: 6752-6761.

[15] Lin J-C, Kunz HR, Fenton MF, Fenton SS. The fuel cell -an ideal chemical engineering undergraduate experiment, 2013 Proceeding of the 2003 American Society for Engineering Education Annual Conference \& Exposition, session 2313.

[16] Pelin Y, Haken M, Hocaoglub, Konukmanc AS. A prefeasability case study on integrated planning including renewable. Energy Policy 2008; 36: 1223-1232. http://dx.doi.org/10.1016/j.enpol.2007.12.007

[17] El-Shatter ThF, Eskandar MN, El-Hagary MT. Hybrid PV/fuel cell system design and simulation. Renewable Energy 2002; 27: 479-485. http://dx.doi.org/10.1016/S0960-1481(01)00062-3

[18] Ikhsan M, Purwadi A, Hariyanto $H$, Heryana N, Haroen $Y$ Study of renewable energy sources capacity and loading using data logger for sizing of solar-wind hybrid power system, 4th International Conference on Electrical Engineering and Informatics (ICEEI) 2013. http://dx.doi.org/10.1016/j.protcy.2013.12.293

[19] Zonhan Y. Wind Power Co. Ltd., Operating \& installation manua, ZH1.5kw wind turbine system 2015.

[20] Bosma B, Kallio G. Renewable -energy labs for an undergraduate energy-systems course, American Society for Engineering Education 2009.

[21] Benghanem S, MS., Alamri SN. Modeling of photovoltaic module and experimental determination of serial resistance" JTUSCI, 2008; August.

[22] Ramon A, Lopez, Maritz A, Angarita G. Parametros comparatives de celulas fotoelectricas para generaciob de energia: implementacion de banco de pruebas usando DSP comparative parameters of solar cells for power generation: test stand implementation using DSP. Ingeniería Energética 2014; XXXV, (3/2014), 193- 201, Septiembre/Diciembre ISSN 1815-5901.

[23] Feroldi D. Serra M, Riera J. Performance improvement of a PEMFC system controlling the cathode outlet air flow. J Power Sources 2007; 169(1): 205-212. 